\title{
Alternate Strip Clearcutting in Upland Black Spruce VII. Planning and Implementation
}

\author{
by
}

\author{
Lorne D. Morrow ${ }^{1}$
}

\begin{abstract}
Planning and organization of operational strip cutting was demonstrated with a 4500 -ha study block scheduled for harvest by Domtar Forest Products during the 1986-1988 annual work schedule periods. The potential impact of two harvesting systems on road intensity and subsequent strip delineation and layout was examined. Specifically, conventional "cutand-skid" harvesting, with maximum skidding distances of $180 \mathrm{~m}$, resulted in $13.3 \mathrm{~km}$ of production road within the study area over and above that obtained with a fully mechanical-to-roadside system (360- $\mathrm{m}$ maximum skidding distance). Furthermore, the mechanical system reduced fragmentation of the cutting pattern and established relatively long leave strips, factors that should reduce volume losses from windfall and mortality. The step-by-step procedures for operational planning, layout and harvest of this proposed modified cut study area are examined and described.
\end{abstract}

\section{Résumé}

La planification et la répartition des coupes en bandes ont été réalisées sur une placette de 4500 ha devant être exploitée par la société Domtar Forest Products en 1986-1988. L'impact potentiel de deux modes d'exploitation forestière sur la charge routière et la délimitation et le tracé subséquents des bandes a été examiné. Plus particulièrement, la méthode classique d'abattage-débusquage (distance maximale de traînage de $180 \mathrm{~m}$ ), a résulté en une route forestière de $13,3 \mathrm{~km}$ en plus de celle obtenue avec une méthode d'abattage entièrement mécanique avec portage en bordure des routes (distance maximale de traînage de $360 \mathrm{~m}$ ). De plus, la méthode mécanique a permis de limiter la fragmentation du modèle d'abattage et d'obtenir d'assez longs rideaux d'arbres, ce qui devrait entraîner une réduction des pertes de volume dues au chablis et à la mortalité. Les méthodes de planification opérationnelle, de jalonnement et d'exploitation forestière de cette nouvelle surface d'exploitation proposée sont examinées et décrites.

\section{Introduction}

The operational use of modified harvest cutting as a silvicultural tool in northwestern Ontario has been described by Auld (1975) and Peacock (1975). Domtar Forest Products, Red Rock Division, has been involved with modified havest cutting of black spruce (Picea mariana [Mill.] B.S.P.) on the Lake Nipigon forest in north central Ontario for more than 15 years. This includes the period when the Ontario Ministry of Natural Resources (OMNR) was responsible for regeneration and the period after 1981 when Domtar assumed responsibility for regeneration under its Forest Management Agreement (FMA) with the province. Marek (1975) discussed the successful regeneration of shallow-soiled black spruce in the Lake Nipigon-Beardmore area of northwestern Ontario by means of modified harvest cutting and felt that the technique was a good tool for regenerating black spruce on these fragile sites. As discussed by Robinson (1987), Domtar has been an active cooperator in many of the long-term research studies in modified harvest cutting in the Nipigon forest.

The Red Rock Division of Domtar Forest Products manages the Lake Nipigon Forest Agreement area of 6129

Domtar Forest Products, P. O. Box 480, Red Rock, Ontario POT 2P0 $\mathrm{km}^{2}$ as well as the Domtar-Armstrong Management Unit $\left(8131 \mathrm{~km}^{2}\right)$. Both areas supply wood fibre to the linerboard and newsprint mill in Red Rock on a sustained yield basis (Fig. 1).

The purpose of this paper is to describe the procedure used by Domtar in the planning and implementation of alternate strip cutting. An operational strip-cut area, scheduled for harvest during the period 1986-1988, formed the model for this alternate strip-cutting exercise. Major operational constraints and benefits are discussed.

Two different road intensities have been modelled in the experimental area. The first is based on a conventional cutand-skid logging system that uses manual felling with limbing and topping on the site with a $180-\mathrm{m}$ maximum skid distance. The second is based on a 360-m skid distance and uses fully mechanical felling (i.e., feller bunchers) and whole-tree to roadside skidding. The latter was included since mechanical felling is becoming increasingly more common in modern harvesting operations. The longer $(360-\mathrm{m})$ maximum skidding distance will be used in logging the majority of the area.

\section{Study Area}

The study is situated in the Vincent Creek portion of Domtar's Unit 93 operating area about $20 \mathrm{~km}$ east of 


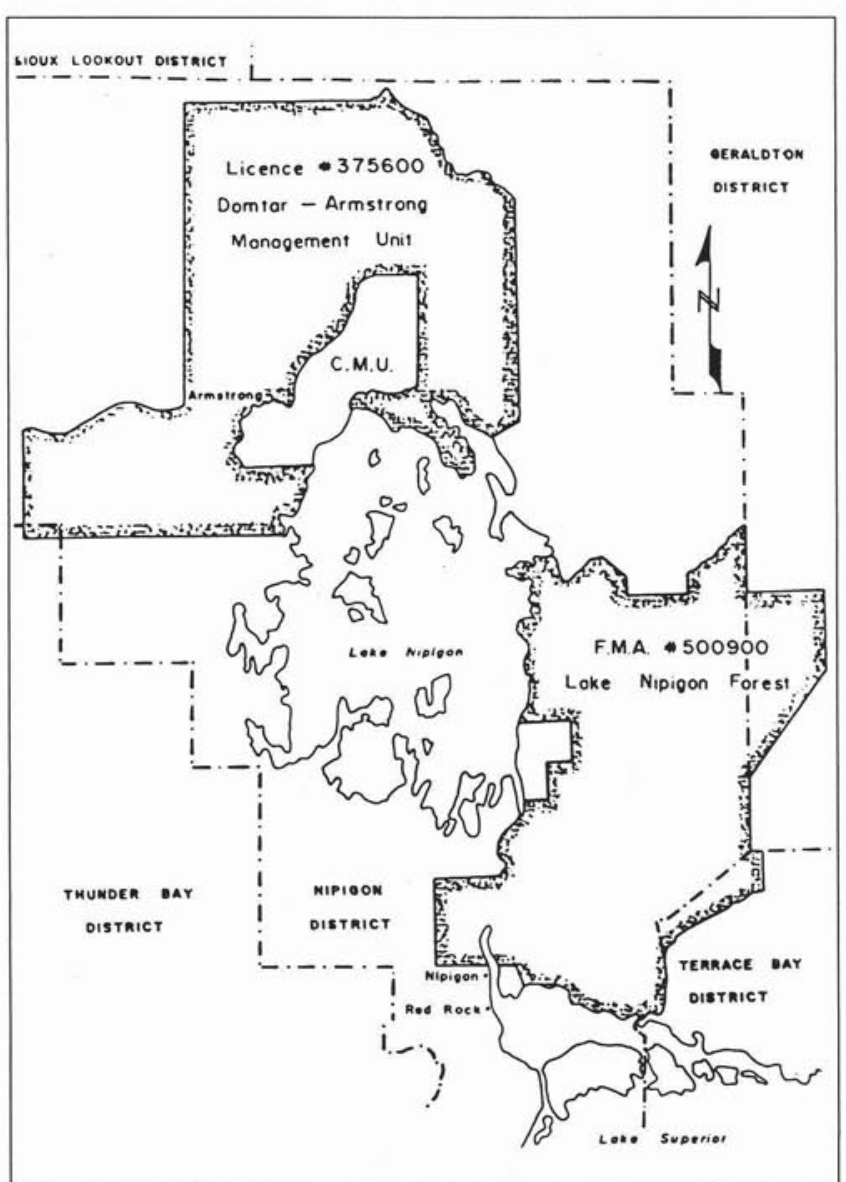

Figure 1. Location of the Lake Nipigon Forest.

Beardmore and $60 \mathrm{~km}$ north of Nipigon (Fig. 2). This is within Site Region 3W (Hills 1960) and the Central Plateau Section (B.8) of the Boreal Forest Region (Rowe 1972). In earlier studies conducted in this area, Jeglum $(1980,1982,1984)$ has described soil, site, topographic and climatic factors in detail.

The 4 500-ha area, located in the northwest quadrant of base map 495873 (Vincent Township), is one of the few concentrated areas of homogeneous spruce forests in this operating plan period (1986-1988) suitable for extensive modified harvest cutting (Fig. 3 ). The area is a mix of highly variable upland and lowland shallow-soiled bedrock-controlled sites typified by Domtar site types 1,2 and 3 (Table 1).

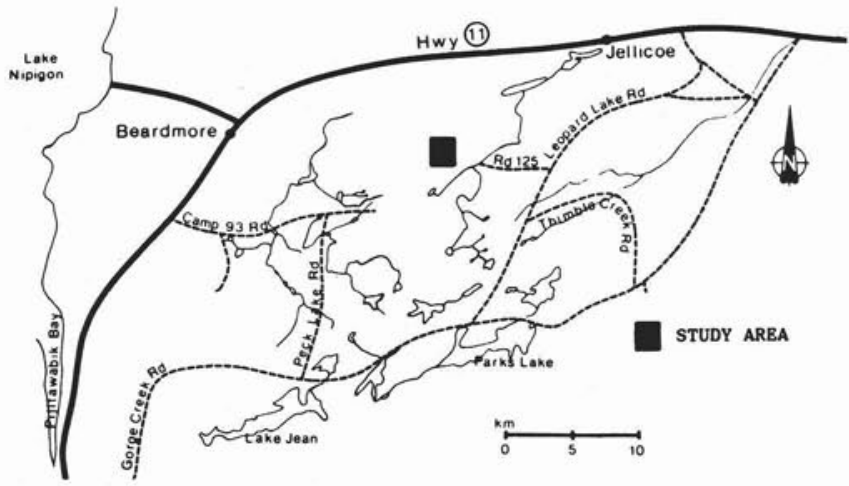

Figure 2. Location of the study area

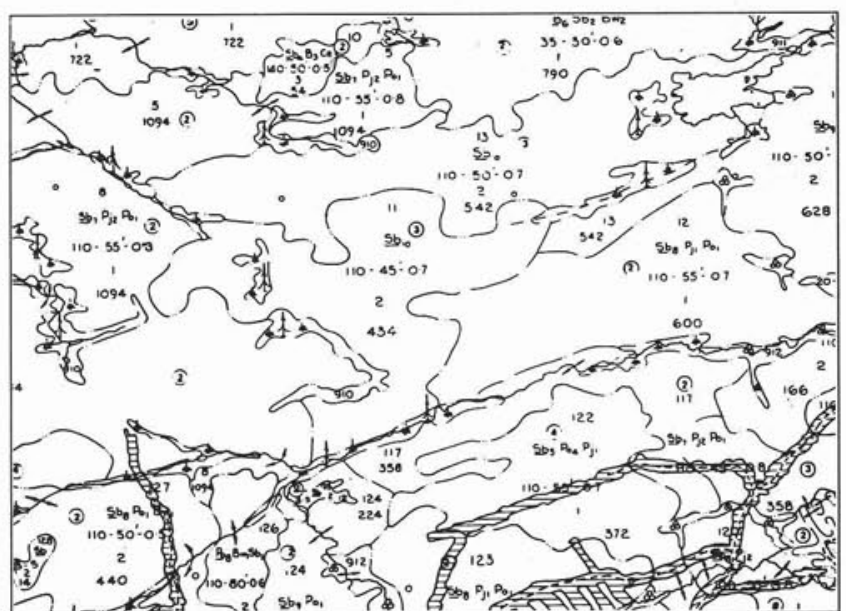

Figure 3. Conventional stand typing of the study area.

Within this study area, the following harvesting operations have been proposed for the period 1986-1988:

Size of study area

4515 ha

Five-year allocation plan in study area

2645 ha Area to be stripcut

936 ha

The forest stands within the area are predominantly spruce and spruce-pine mixtures of fire origin ranging in age from 125 to 135 years. Black spruce is the dominant tree species and Schreber's feather moss (Pleurozium schreberi [Brid.] Mitt.) is abundant. Other tree species present in lesser amounts are balsam fir (Abies balsamea [L.] Mill.), jack pine (Pinus banksiana Lamb.), trembling aspen (Populus tremuloides Michx.) and white birch (Betula papyrifera Marsh.) (Jeglum 1984). Gross merchantable volumes average $130 \mathrm{~m}^{3} / \mathrm{ha}$ and stand densities are approximately 1000 stems/ha.

Before 1983, all wood was harvested by means of threeman conventional cut-and-skid crews using chainsaws and wheeled skidders. Recently, Domtar has converted to fully mechanized felling and whole-tree skidding to roadside. Only isolated stands and sites that are too rugged for mechanical felling are cut by conventional cut-and-skid crews. Wood is mechanically delimbed at roadside, slashed into 2.4-m lengths, or whole-tree chipped and transported to the Domtar mill in Red Rock, Ontario.

Road networks at 180 - and 360-m maximum skid distances are illustrated in Figures 4 and 5 . Secondary roads, as defined and subsidized under the FMA, are outlined on both figures and do not change with the variation in skidding distance because the secondary road corridors have been finalized and approved in the existing timber management and operating plans.

Road statistics for the study area are summarized below:

180-m maximum skidding distance

Secondary roads

$25.3 \mathrm{~km}$

Tertiary roads

$52.0 \mathrm{~km}$

Total

$77.3 \mathrm{~km}$

360-m maximum skidding distance

Secondary roads

$25.3 \mathrm{~km}$

Tertiary roads

$38.7 \mathrm{~km}$

Total

Net road saving

$13.3 \mathrm{~km}$ 


\begin{tabular}{|c|c|c|c|c|}
\hline Class & Topography & Soil & Stand description & Logging chance \\
\hline $\begin{array}{l}\text { 1. Spruce } \\
\text { flat }\end{array}$ & flat & organic or clay & black spruce and/or cedar & generally winter \\
\hline $\begin{array}{l}\text { 2. Softwood } \\
\text { slope }\end{array}$ & $\begin{array}{l}\text { gently rolling to hilly with no } \\
\text { drastic changes in topo- } \\
\text { graphy; gradual }\end{array}$ & $\begin{array}{l}\text { silt and sandy loams, often } \\
\text { with boulder till }\end{array}$ & $\begin{array}{l}\text { black and white spruce, bal- } \\
\text { sam fir, jack pine, occasional } \\
\text { poplar and white birch (up to } \\
30 \% \text { cover) }\end{array}$ & generally summer \\
\hline $\begin{array}{l}\text { 3. Irregular } \\
\text { softwood } \\
\text { site }\end{array}$ & $\begin{array}{l}\text { gently rolling to hilly; drastic } \\
\text { breaks in topography }\end{array}$ & $\begin{array}{l}\text { thin loamy soils over bed- } \\
\text { rock interspersed with } \\
\text { pockets of organic and/or } \\
\text { till }\end{array}$ & $\begin{array}{l}\text { predominantly black spruce; } \\
\text { less than } 30 \% \text { cover of poplar } \\
\text { and/or white birch }\end{array}$ & generally winter \\
\hline $\begin{array}{l}\text { 4. Mixedwood } \\
\text { slope }\end{array}$ & $\begin{array}{l}\text { gently to deeply rolling; also } \\
\text { rounded summits and ridges }\end{array}$ & $\begin{array}{l}\text { moderately deep, sandy, } \\
\text { silty or clay tills with some } \\
\text { boulder till }\end{array}$ & $\begin{array}{l}\text { various mixtures of balsam fir, } \\
\text { white and black spruce, jack } \\
\text { pine, poplar and white birch } \\
\text { cover from } 25 \text { to } 75 \%\end{array}$ & generally summer \\
\hline 5. Jack pine & $\begin{array}{l}\text { flat to deeply rolling; glacio- } \\
\text { fluvial formations such as } \\
\text { eskers, outwash plains, etc. }\end{array}$ & $\begin{array}{l}\text { deep sands, gravels and } \\
\text { loamy sands }\end{array}$ & $\begin{array}{l}\text { predominantly jack pine with } \\
\text { spruce; occasional poplar and } \\
\text { summer white birch; jack pine } \\
\text { cover } 30 \% \text { and upward }\end{array}$ & summer \\
\hline $\begin{array}{l}\text { 6. Rugged } \\
\text { upland }\end{array}$ & $\begin{array}{l}\text { extremely hilly; very steep to } \\
\text { rough slopes; shallow to steep } \\
\text { ravines bedrock controlled }\end{array}$ & $\begin{array}{l}\text { shallow soils or thin till } \\
\text { mantles over bedrock }\end{array}$ & all species & $\begin{array}{l}\text { extremely difficult in all } \\
\text { seasons }\end{array}$ \\
\hline $\begin{array}{l}\text { 7. Hardwood } \\
\text { slope }\end{array}$ & flat to hilly & $\begin{array}{l}\text { moderately deep, sandy, } \\
\text { silty or clay tills with some } \\
\text { boulder till }\end{array}$ & $\begin{array}{l}\text { poplar and white birch cover } \\
\text { greater than } 75 \%\end{array}$ & summer \\
\hline $\begin{array}{l}\text { 8. Irregular } \\
\text { mixedwood }\end{array}$ & bedrock controlled & $\begin{array}{l}\text { shallow soils or thin till } \\
\text { mantles over bedrock }\end{array}$ & $\begin{array}{l}\text { poplar and white birch cover } \\
30-100 \%\end{array}$ & $\begin{array}{l}\text { extremely difficult in all } \\
\text { seasons }\end{array}$ \\
\hline
\end{tabular}

\section{Precut Planning}

\section{Fine Typing}

Figure 3 illustrates the conventional typing of the study area. Prior to cut layout within the study area, the entire area was retyped from aerial photographs to a finer detail than is available with conventional forest stand typing. Minimum map unit size with conventional stand typing is $5 \mathrm{ha}$. This broad resolution of stand boundaries makes field delineation and definition extremely difficult. Peacock (1975) described similar detailed mapping as a necessary step in undertaking modified harvest cutting. In his experience, five person-days were needed to fine type, transfer and prepare the new working map.

Fine typing revealed that the forest is generally older than that described by the conventional inventory. As well, the continuous stands are beginning to break up, as is exemplified by the blowdown pockets and reduced stocking on the finetype mapping. Since this particular forest averages 130 years, a two-pass 60-m cut, 60-m alternate leave strip-cut system was selected. Removal of the second cuts is scheduled after three or four growing seasons. Any delay of the second cuts could result in unacceptable losses to blowdown (Fleming and Crossfield 1983).

\section{Road Location}

Final road and new road corridor locations were transferred to the "fine-type" map by means of current supplementary aerial photography $($ scale $=1: 15840)$. Although every effort was made to align the roads in east and west directions, directional alignment was not the primary factor in road location.

The two road intensities (180- and 360-m skid distance) were illustrated in this study to show how mechanization can reduce road intensity. Under a conventional cut-and-skid system, existing union agreements restrict maximum skid distances to $180 \mathrm{~m}$. However, with mechanized felling, skidding distances can be doubled, with the result that there is $25 \%$ less tertiary road. This is a very significant saving in view of the high cost of road construction under these shallowsoiled, broken topographic conditions. Mechanized felling also allows for better control of strip width since strip width can simply be converted into felling passes per machine (usually four or five passes for a 60-m strip).

\section{Strip Layout}

All tertiary roads were located, and strips were marked according to the following rules:

1. Align strips north and south where possible.

2. Have only one end of the strip open.

3. Wherever possible amalgamate the second cut with any residual bypass areas or protection forest swamps.

Tentative cut layouts for the study area are illustrated in Figure 6. Final strip layout for the 1987 and 1988 operating seasons may be altered after precut inspections if there are considerable terrain and equipment restrictions.

\section{Implementation}

When precut planning has been completed, strip layout and tertiary road location are supervised or implemented by Domtar's Forestry Department. In the Red Rock Division of Domtar, the photogrammetrist also assists the roads foreman in the location of roads. Therefore, implementation of this type of road location and strip layout is a natural extension of normal job functions. Furthermore, it allows the photogrammetrist to ground-truth proposed road locations and cut 


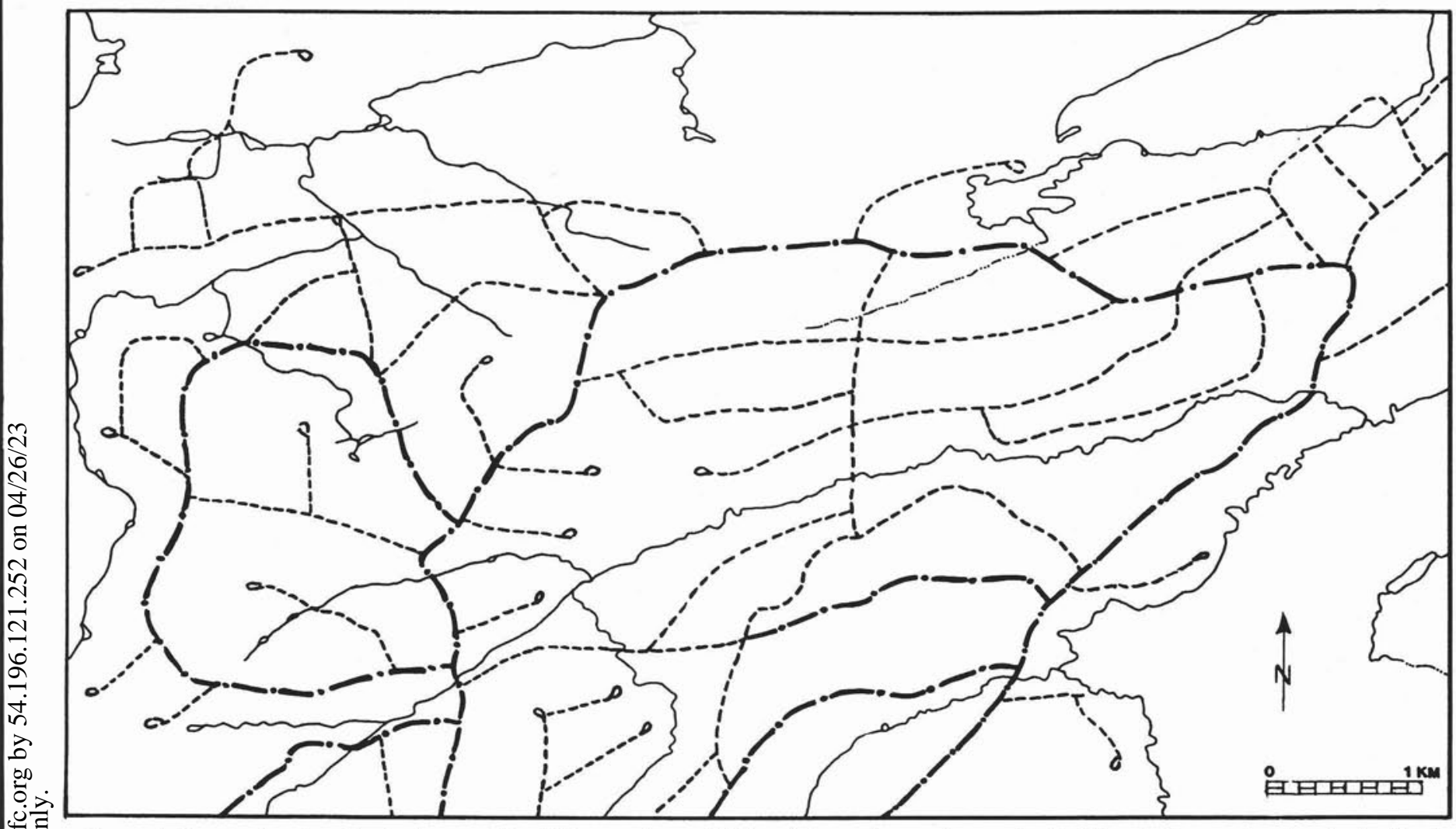

Figure 4. Road network on the study area with a $180 \mathrm{~m}$ maximum skidding distance. (secondary roads = bold line; tertiary roads $=$ fine dashed line)

alignments, thereby improving overall layout and photogrammetric skills.

Fine-type mapping is very helpful to our staff in conventional clearcut layout and particularly in stripcut layout. All annual work schedule maps submitted to the operational staff include this type of mapping in areas in which modified cutting is required or cut layout is particularly difficult because of very heterogeneous stand types. Most modified harvest cut layout is controlled and implemented by the Forestry Department. Liaison between the Forestry Department and the operational foreman is conducted on a weekly basis when areas of modified harvest cut are being logged.

\section{Operational Constraints}

\section{Increased Road and Operating Costs}

Peacock (1975) described and Ketcheson (1977, 1979. 1982 ) thoroughly assessed the increased road and operating costs resulting from alternate strip clearcutting. Johnson and Smyth (1987) extended this analysis to include total costs of harvesting and regenerating for numerous regeneration options. They clearly showed that, for all options involving planting, stripcutting would be less expensive than clearcutting. The company now bears the extra cost of modified harvesting and does not receive compensation for these costs. It is suggested that, where a modified harvesting system is employed to procure natural regeneration, the extra costs of harvesting should be regarded as part of the cost of achieving regeneration.

\section{Increased Layout and Planning Costs}

Indirect costs of extra planning and layout increase in direct proportion to the number of hectares of alternate strip cutting. Johnson and Smyth (1987) calculated an extra cost for this additional planning. However, with Ontario forest companies assuming responsibility for regeneration under the FMAs, staff requirements have been increased to meet the need for additional planning and, in Domtar's case, the indirect planning costs are minimal.

\section{Loss Due to Blowdown}

Fleming and Crossfield (1983) have reported volume losses resulting from blowdown. Losses can be minimized through careful cut planning and layout and through prompt harvesting of the second cut. It has been suggested that a leave time of three years or more will be required to achieve satisfactory levels of established seedlings (Jeglum 1987).

\section{Reduced Machine and Skidway Flexibility}

This operational constraint is probably the most difficult to control and predict. There will always be specific situations in which original strip alignment cannot be practicably implemented on the ground. The problem increases proportionally as the harvest strip becomes longer and narrower. Only through extensive liaison between the forestry and logging departments can this be reduced. The key is flexibility; forest managers must be prepared to alter modified cut layouts during logging operations on the site. Operational foremen must also be prepared to accommodate silvicultural requirements and prescriptions for that particular stand. 


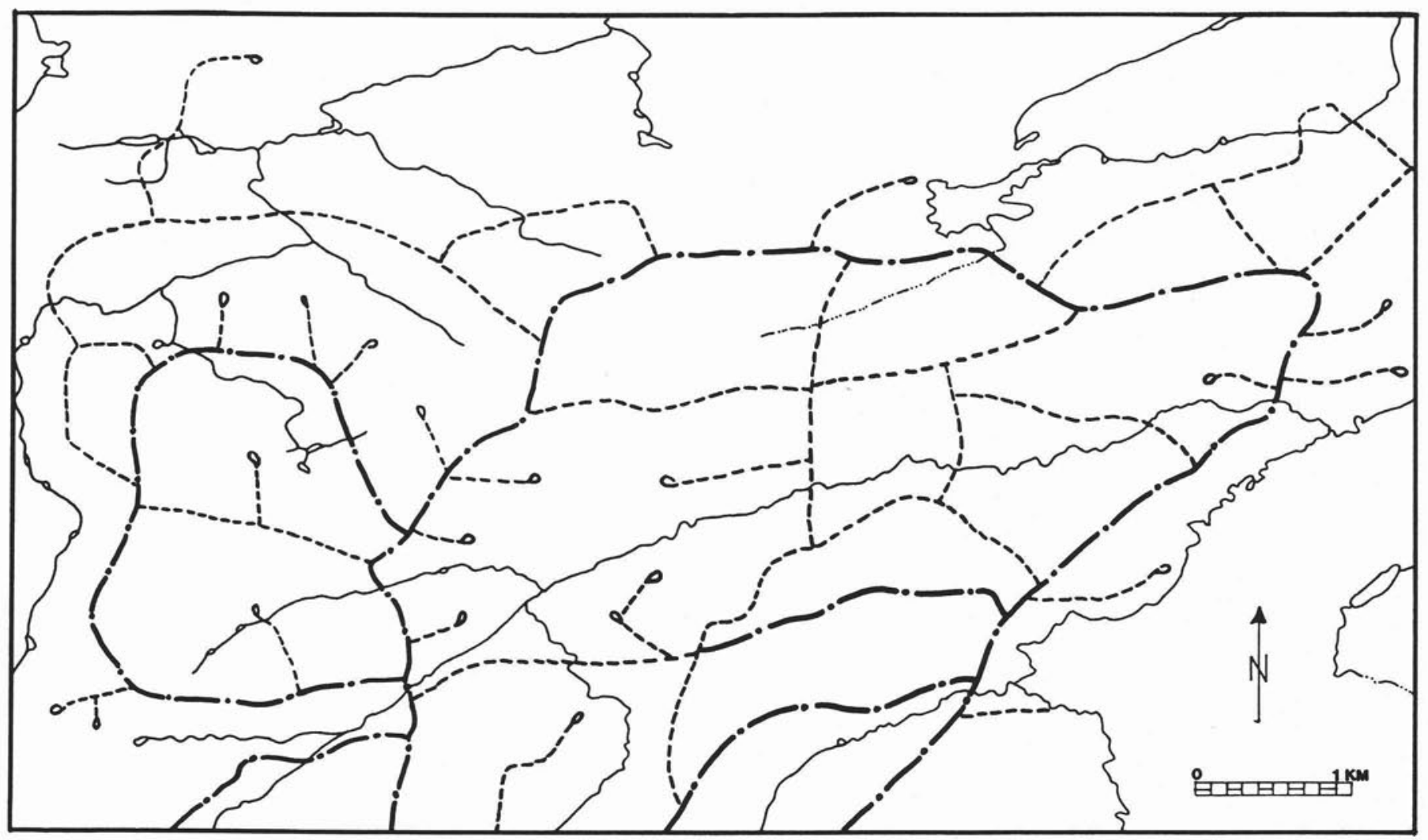

Figure 5. Road network on the study area with a 360 -m maximum skidding distance. (secondary roads = bold line; tertiary roads $=$ fine dashed line)

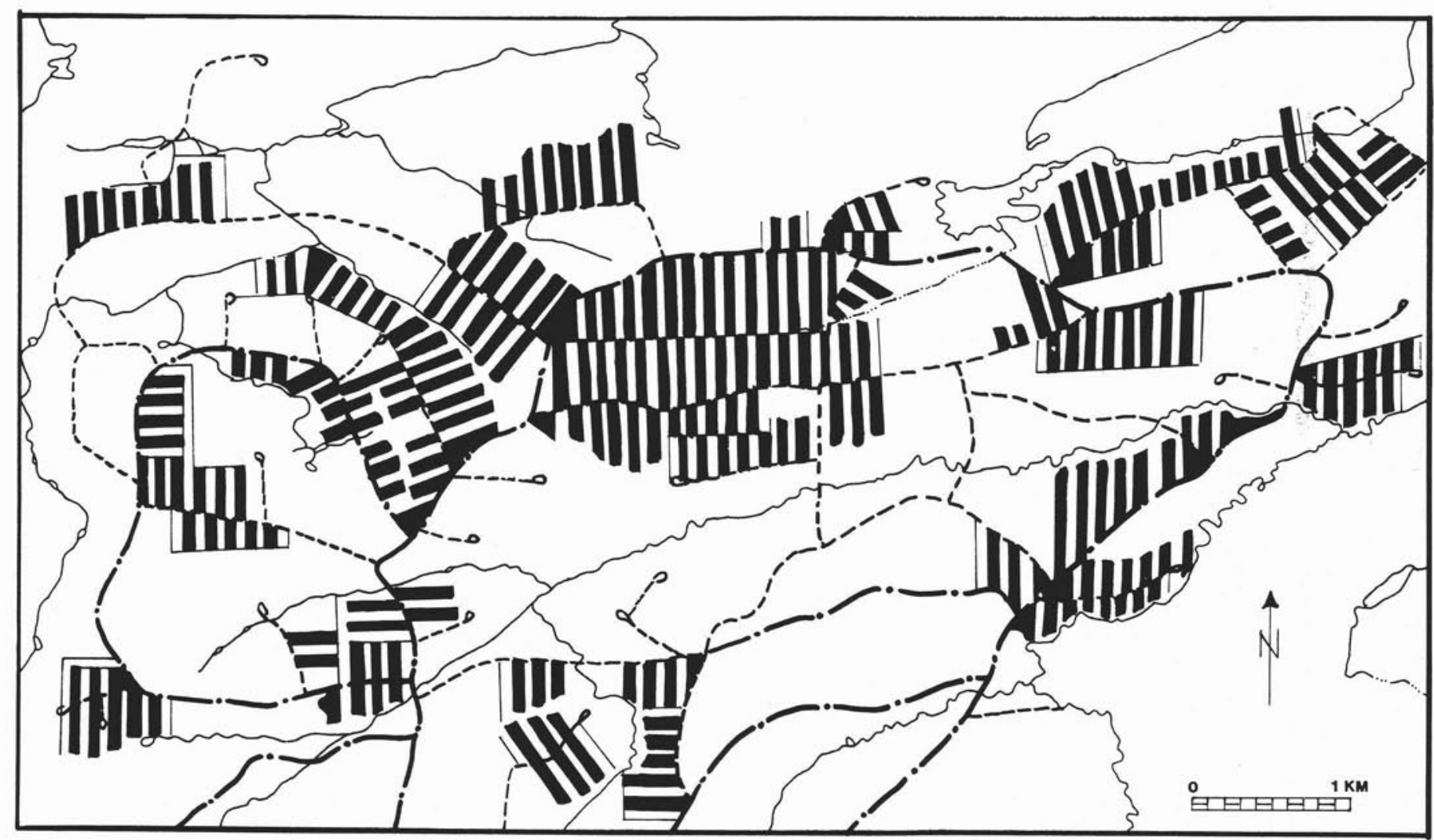

Figure 6. Proposed modified harvest cut layout for the 1986-1988 operating period. (first-cut strips outlined in black) 


\section{Operational Benefits}

\section{Improved Planning and Cut Coordination}

Alternate strip cutting improves planning and cut coordination. Since accurate precut inspections, road locations and strip layouts are essential to the effective implementation of modified harvest cutting, Domtar realizes an indirect gain through an efficiently planned harvest system and better liaison between the forestry and logging departments.

\section{Reduced Regeneration Costs}

The ability to regenerate shallow spruce sites naturally results in a direct cost saving to Domtar and permits planting stock to be concentrated on more productive "prime site" areas. OMNR also benefits because silvicultural subsidies paid to Domtar and demand for quality planting stock are reduced - a major benefit because demand for planting stock is approaching nursery production capacities.

\section{Prime Site Management}

The concept of modified or strip cutting for natural regeneration complements "prime site" management since it is regarded as an extensive method of forest management that permits more intensive management practices to be concentrated on better growing sites.

\section{Recommendations}

1. Precut and postcut planning must be detailed and should include a prompt regeneration schedule for first-cut strips as well as a definite timetable for second-cut strips.

2. Skidding distances should be maximized to reduce production road costs and to minimize losses due to windfall.

3. It must be recognized that alternate strip cutting is an extensive form of forest management and regeneration obligations and requirements must be redefined so that strip cutting will be a feasible alternative for treating difficult and fragile sites.

\section{Acknowledgments}

I gratefully acknowledge the assistance of T. Oyakawa, who finetyped the experimental study area and implemented the cutting patterns on the ground. I also thank J. Jeglum and J. Wood for critical review of this manuscript.

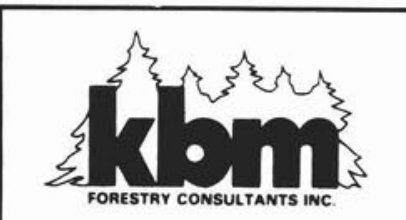

360 mooney street

thunder bay, ontario P7B 5R4

$$
\begin{aligned}
& \text { REFORESTATION EQUIPMENT } \\
& - \text { Sales Service Parts Repair } \\
& \text { REGENERATION \& SITE PREPARATION } \\
& \quad-\text { Contract Assessment Consulting } \\
& \text { 807-344-0811 telex 073-4603 }
\end{aligned}
$$

\section{Literature cited}

Auld, J.M. 1975. Modified harvest cutting in Thunder Bay District. $p$. 201-206 in Black spruce symposium. Dep. Environ., Can. For. Serv., Sault Ste. Marie, Ont. Symp. Proc. 0-P-4.

Fleming, R.L. and Crossfield, R.M. 1983. Strip cutting in shallow soil upland black spruce near Nipigon, Ontario. III. Windfall and mortality in the leave strips, preliminary results. Dep. Environ., Can. For. Serv., Sault Ste. Marie, Ont. Inf. Rep. 0-X-354. 27 p. + appendices.

Hills, G.A. 1960. Regional site research. For. Chron. 36: 401-423.

Jeglum, J.K. 1980. Strip cutting in shallow-soil upland black spruce near Nipigon, Ontario. I. Study establishment and site conditions. Dep. Environ., Can. For. Serv., Sault Ste. Marie, Ont. Report 0-X-315.61 p.

Jeglum, J.K. 1982. Strip cutting in shallow-soil upland black spruce near Nipigon, Ontario. II. Regeneration in the first study area. Dep. Environ., Can. For. Serv., Sault Ste. Marie, Ont. Inf. Rep. 0-X-337. $24 p$

Jeglum, J.K. 1984. Strip cutting in shallow-soil upland black spruce near Nipigon, Ontario. III. Seedling-seedbed relationships. Dep. Environ., Can. For. Serv., Sault Ste. Marie, Ont. Inf. Rep. $0-X-359.26 \mathrm{p}$.

Jeglum, J.K. 1987. Alternate strip clearcutting in upland black spruce. II. Factors affecting regeneration in first-cut strips. For. Chron. 63: 439-445

Johnson, J.D. and Smyth, J.H. 1987. Harvesting and renewal costs of stripcutting and clearcutting on shallow-soil upland black spruce sites in north central Ontario. Gov't of Can., Can. For. Serv., Sault Ste. Marie, Ont. Inf. Rep. 0-X-380.

Ketcheson, D.E. 1977. The impact of strip cutting on logging road costs. Dep. Fish. Environ., Can. For. Serv., Sault Ste. Marie, Ont. Report 0-X-263. $19 p$

Ketcheson, D.E. 1979. A study of the cost of strip cutting black spruce stands in northern Ontario. Dep. Environ., Can. For. Serv., Sault Ste. Marie, Ont. Report 0-X-301.23 p.

Ketcheson, D.E. 1982. The impact of strip cutting on logging costs: Additional road construction and maintenance are the key factors which incur extra costs. Pulp Pap. Mag. Can. 83(7): 2934.

Marek, G.T. 1975. Ecosystem management of black spruce on shallow sites in the Lake Nipigon-Beardmore area. p. 195-200 in Black spruce symposium. Dep. Environ., Can. For. Serv., Sault Ste. Marie, Ont. Symp. Proc. 0-P-4.

Peacock, T.H. 1975. Operational problems of modified cut harvesting. p. 207-218 in Black spruce symposium. Dep. Environ., Can. For. Serv., Sault Ste. Marie, Ont. Symp. Proc. 0-P-4.

Robinson, F.C. 1987. Alternate strip clearcutting in upland black spruce. I. An introduction. For. Chron. 63:435-438.

Rowe, J.S. 1972. Forest regions of Canada. Dep. Environ., Can. For. Serv., Ottawa, Ont. Publ. No. 1300. 172 p.

\section{EDWARD \\ $S$. FELLOWS \\ MEMBER: \\ Canadian Institute of Forestry Forest Products Research Society etc. \\ FORESTRY \& FOREST PRODUCTS CONSULTANT}

Mail address:

P.O. Box 354

FREDERICTON, N.B.

E3B $4 Z 9$
Office location: 404 Queen Street, FREDERICTON, N.B. INDUSTRY DEVELOPMENT - FOREST PRODUCTS FOREST ECONOMICS, POLICY AND ADMINISTRATION 